\title{
RESPONDEAT SUPERIOR IN AUTOMOBILE NEGLIGENCE- AN ANOMALY IN THE FEDERAL TORT CLAIMS ACT
}

ACCIDENT victims of commercial vehicles normally seek to recover from financially responsible owners rather than from employee-drivers. But under the common law doctrine of respondeat superior, an employer is not liable for the negligence of his employee unless the latter is acting within the scope of his employment at the time of the wrongful act." Since the "scope of employment" test generally requires the employee to be furthering his employer's business interest when the negligent act occurs, ${ }^{2}$ use of a vehicle by an employee for purely personal reasons usually exempts the employer from liability. ${ }^{3}$ And even where such private use may have been with the employer's permission, he can escape liability under the doctrine. The most an injured claimant can get is an often uncollectible personal judgment against the employee. 5

But in practice, state statutes and accident insurance provisions facilitate recovery for injuries caused by negligent employee-drivers. ${ }^{B}$ Statutory pro-

1. See, e.g., Riddle v. Whisnant, 220 N.C. 131, 134, 16 S.E 2d 698, 701 (1941); Mister Auto Service Corp. v. Bowden, 179 Va. 507, 510, 19 S.E. 2d 679, 6SD (1942).

2. See, e.g., Miontgomery v. Hutchins, 118 F. $2 d$ 661, 664 (9th Cir. 1941); Holder v. Haynes, 193 S.C. 176, 187, 7 S.E. 2d 833, 838 (1940). Tifraisy, Principal ahi Agent 106 (2d ed. 1924); Restateasent, Agency $\$ \$ 228,235$ (1933).

3. See, e.g., Louis Pizitz Dry Goods Co. v. Driesbach, 30 Ala. App. 159, 4 So. $2 d$ 180 , cert. dertied, 241 Ala. 668, 4 So. 2d 182 (1941). Slight deviations from the scope of employment, however, do not necessarily relieve the employer of liability. See, c.g., Small v. Shull, 190 Okla. 418, 124 P. 2d 381 (1942). See Smith, Frolic and Detour, 23 COL. L. REv. 444, 716 (1923).

4. See, e.g., Brown v. Chevrolet Motor Co. of California, 39 Cal. App. 738,179 Pac. 697 (1919); Fisher v. Fletcher, 191 Ind. 529, 133 N.E. 834 (1922); Sec Montgomery v. Hutchins, 118 F. 2d 661, 662 (9th Cir. 1941).

5. See James, Accident Liability Reconsidercd: The Impaet of Liability Insuranec, 57 Yaze L. J. 549, 564 (1948) ; Corstret, The Uncompensated Accident on:d Its Conscquences, 3 LAW \& CONTENSP. Prob. 466 (1936).

6. See Young v. Masci, 289 U.S. 253, 259 (1933) (criticism of respondeat superior and discussion of statutory and common law developments broadening liability); see James, suprc note 5 , at 563 (effect of insurance on recovery). The doctrine of respondeat superior probably survives today only because various inroads upon it have removed much of its sting. See James, supra note 5, at 569. Grad, Recent Derelopments is Autonobile Accident Compensation, 50 CoL L. REr. 300, 305 (1950). In addition to the changes discussed in note 7 infra, one of the methods developed by state legislatures and courts to expand common law liability and thereby achieve "practical responsibility" has been the use of presumptions of agency. Almost all jurisdictions have rules permitting the plaintiff to establish such a prima facie case or presumption from varying quanta of proof. See Fegan, Presumption versus Proof in Aufomobile Highuray Accidents, 22 Geo. L. J. 750, 
visions in at least ten jurisdictions are applied to hold employers liable for the negligence of their employees, regardless of scope of employment restrictions, if the vehicle is used with the employer's consent. ${ }^{7}$ Moreover, "omnibus clauses" in virtually all private and commercial accident liability policies include within their definition of "insured" any employee driving with the consent of his employer. ${ }^{8}$ Such insurance is already widely-held, and the

790 (1934). For a general discussion of the various standards used, sec Department of Water and Power v. Anderson, 95 F. 2d 577, 584 (9th Cir. 1938), cert. denicd, 305 U.S. 607 (1938). Another device used to provide a financially responsible defendant in a somewhat analogous situation is the "family car doctrine." Employed in approximately half the jurisdictions, this doctrine imposes liability upon the owner of a vehicle for the negligence of members of his family when he allows them to use it. SHuLaran \& JAMEs, Cases and Materials on the Law of Torts 665 (1942): Note, 16 Notre Dame Law. 394, 395 (1940).

7. Such statutes generally make an owner responsible for the negligence of anyone using a vehicle with his express or implied permission. DeERING's CALIF. Cone, Veir. Code Ans. \&402 (1948); D.C. Code \$ 40-403 (1940); IDsmo Code ANN. \$ 49-1004 (1948) ; Iowa Code ANn. \$321.493 (1949); Mich. STat. ANn. \$9.2101 (Supp. 1940); Minn. Stat. Ann. $\$ 170.54$ (1946); N.Y. Veh. \& Traffic Law $\$ 59$ (Supp. 1951); R.I. Gen. Laws 1938, c. 98, $\S 10$ (1938), as amended by Pug. Laws 1940, c. 867, $\S 1$; Wis. STAT. $\$ 85.01$ (1a) (c) (1949).

In Florida there is no such statute. But the courts have held that under the common law an owner is liable for the negligence of anyone using his automobile with his express or implied permission. Southern Cotton Oil Co. v. Anderson, 80 Fla. 441, 86 So. 629 (1920); accord, D'Allessandro v. Bechtol, 104 F. $2 d 845$ (5th Cir. 1939).

The combined population of these ten jurisdictions in 1950 was approximately 46,109 ,000 persons. For the United States as a whole in the same year, the total population was $149,856,000$. U.S. Department of Commerce, Bureau of the Census, 1950 Census of Population, series PC-3, No. 10 (preliminary counts Apr. 1, 1950).

8. For a brief discussion of the growth and development of the "omnibus clause," see Drewry, The Omnibus Clanse, 90 Rougr Notes 32 (1947).

The typical standard private policy clause is as follows: "... [T] he unqualified word 'insured' includes the named insured and also includes any person while using the automobile and any person or organization legally responsible for the use thereof, provided the actual use of the automobile is by the named insured or with his permission." Travelers Insurance Company and Travelers Indemnity Company policy, form $\mathrm{MV}$, in Yale Law Library. For the older form of this standard policy provision, see SAwYeat, AutomoBne IIABLITY INSURANCE 86 (1936).

Although not all companies writing automobile liability insurance utilize all the stand. ard policy provisions adopted by members of the American Mutual Alliance and the National Bureau of Casualty Underwriters, one authority believes that over 99 per cent of the policies issued in the United States include a definition of insured comparable to that given above. Communication to the Yale LAw Jourand from John S. Hamilton, Jr., Assistant General Manager, American Mutual Alliance, dated November 23, 1951, in Yale Law Library. Some states require that omnibus coverage be included in all policies. See, e.g., CoDE of VA. §38-238 (1950). Furthermore, most states having fintncial responsibility laws require that policies issued to comply with such laws carry omnibus clauses.

Standard policies for large commercial enterprises, e.g., garages, formerly covercd only the legal liability of the named insured unless an extra premium were paid to pro- 
pressure of stricter driver's financial responsibility laws tends constantly to increase the number of vehicles covered.$^{10}$ As a result, accident victims negligently injured by vehicles of private businesses can generally recover.

vide extended coverage. Shularan \& James, op. cit. stipra note 6, at 694. Thus coverage for such commercial vehicles extended only to the narrow limits set by the doctrine of respondeat superior. But progressive activity on the part of the insurance companies themselves has led to a broadening of such policies so that now any permissive use of such company-owned vehicles by employees is covered by the terms of the policy. Ser, e.g., Travelers forms FAS (commercial), FG (garage), and SLA (comprehensive), in Yale Law Library. The standard provisions of these policies contain essentially the same definitions of insured as that given in the private automobile policy .

For detailed analysis of the vital role of automobile liability insurance in motor vehicle accident compensation, see James, supra note 5; Grad, sispra note 6 .

9. While no modern nationwide figures are available on the extent of automobile liability insurance, in Miassachusetts, where there is a compulsory insurance lav, all vehicles are covered; in New York, roughly 94 per cent of the registered vehicles are insured; in New Hampshire from $\$ 5$ to 90 per cent; and in Californin 80 per cent. Communication to the Yale LAw Journal from W.H. Brewster, Mianager, Automobile Division, National Bureau of Casualty Underwriters, dated November 5, 1951, in Yale Law Library. Many other states with security-type financial responsibility laws comparable to the New York law make estimates of insured vehicles at from 70 to $90 \mathrm{per}$ cent. Some states, however, estimate that insured vehicles are as low as 25 to 30 per cent. Such percentage estimates apply mainly to private passenger vehicles. Commereial vehicles in most states are subject to some form of compulsory financial responsibility requirement and a very high percentage of such vehicles is either insured or has qualified as a self-insurer. Communication to the Yale Law Journal from John S. Hamilton, Jro, supra note 8. In Maryland, for example, all commercial vehicles must be insured or covered by a bond. Mid. ANN. Code GeN. Laws art. $56 \$ 182$ (1939).

See also the results of an extensive market survey conducted by the Hartford Accident and Indernnity Company in 1950. Of about 23,000 private individuals contacted, approximately 90 per cent carried automobile liability insurance. Of about 21,000 business proprietors and managers, roughly \&4 per cent held such insurance. Although this survey was conducted on a nationwide basis, it does not necessarily represent accurate national percentage since true polling techniques apparently vere not utilized. 51 BEsr's Irss. News 35 (No. 8, 1950).

10. The percentage of insured vehicles in any state apparently jibes with the strictness of its financial responsibility law. In New York, for example, only about 30 per cent of the vehicles were insured in 1942. A year later, after the passage of a law requiring drivers to furnish security when they become involved in an accident, this percentage had jumped to about 75 per cent and has now reached approximatcly 94 per cent. Similar results have been observed in other states. See Veness, Sofety Respossibility, AS Best's INs. News 37-8 (No. 2, 1947); communication from W. H. Brevster, stspra note 9.

Aside from the compulsory insurance law of Massachusetts, sipra note 9, financial responsibility laws are of two general types: those laws requiring security when a driver has failed to meet a judgment; those requiring security where a driver merely becomes involved in an accident. In both cases, failure to comply results in a suspension of the driver's license. Spottke, Pennsyliania Safoty Responsibility Law, 47 Besr's Iris. News 41 (No. 11, 1947).

The second type of law most effectively stimulates the use of automobile insurance, since the easiest way to comply is to have an insurance policy in effect before the aceident. As a result, states desiring essentially the benefits of compulsory insurance but 
The Federal Tort Claims Act, however, does not provide for this broadened standard of recovery. To supplant Congressional private relief bills, inadequate for the claimant and burdensome for the legislature, ${ }^{11}$ as a means of compensation for persons injured through Government employees' negligence, Congress enacted the Federal Tort Claims Act in 1946.12 But the statute, although apparently aiming to equalize Governmental liability for negligent employees' acts with the liability of private employers under like circumstances in the state in which the accident occurred, expressly limited the Government's liability to negligent acts of its employees acting within the scope of their employment. ${ }^{13}$ And the federal courts, reading this statutory

unwilling to accept it in full have concentrated on strengthening their financial responsibility laws. During the past year alone, at least twelve states (Ark., Ariz., Conn., Ga., Mont, N.Y., Ohio, Ore., Tenn., Texas, Utah, and W.Va.) have enacted new or more stringent laws. 52 EASTERN UNDER WRITER 27 (July 20, 1951).

Since the end of World War II, the increased number and strictness of financial responsibility laws and the nation's prosperity have made automobile insurance onc of the fastest growing businesses in the country. During 1946, 1947, and 1948, the total volume of such policies written increased over one-half billion dollars aunually. 51 Best's Ins. News 18 (No. 7, 1950).

11. The system of compensation through direct Congressional action was necessitated by the unjustified doctrine of sovereign immunity. This system had for many years been subjected to criticism as both unduly burdensome to Congress and unjust to claimants. See SEN. REP. No. 1400, 79th Cong., 2d Sess. 30 (1946). In recommending that stuch immunity be waived, the Senate Judiciary Committee reported that

"[t]he existing exemption [to suit] in respect to common law torts appears incongruous. Its only justification appears to be historical. With the expansion of governmental activities in recent years, it becomes especially important to grant to private individuals the right to sue the Government in respect to such torts as negligence in the operation of vehicles." Id. at 31.

For further criticism of the entire concept of sovereign immunity to suit, see Borchard, Govermment Liability in Tort, 34 Y ALE L. J. 1, 129, 229 (1924); Yankwich, Prablems under the Federal Tort Claims Act, 9 F.R.D. 143, 148 (1949).

12. 28 U.S.C. $\$ \$ 1346($ b), 2671 et seq. (Supp. 1951). For history of the Federal Tort Claims Act and general analyses of its provisions, see Gottlieb, The Federal Torl Clainu Act-A Statutory Interpretation, 35 GEo. L. J. 1 (1946); Yankwich, Problems under the Federal Tort Claims Act, 9 F.R.D. 143; Comments, 56 YALE L. J. 534 (1947); 42 ILI. L. REv. 344 (1947).

13. "...the district courts... shall have exclusive jurisdiction of civil actions on claims against the United States, for money damages... for injury or loss of property, or personal injury or death caused by the negligent or wrongful act or omission of any employee of the Government while acting within the scope of his office or employment, under circumstances where the United States, if a private person, would be liable to the claimant in accordance with the law of the place where the act or omission occurrecl." 28 U.S.C. $\$ 1346$ (b) (Supp. 1951).

Members of the armed forces are included within the definition of "employces," and, for them, "acting within the scope of [their] ... employment" is defined as acting "in line of duty." 28 U.S.C. $\$ 2671$ (Supp. 1951). Federal courts have generally treated this "line of duty" definition as identical with "scope of employment" as applied to private cmployees. United States v. Campbell, 172 F. 2d 500, 503 (5th Cir. 1949), cert. detricd, 337 
restriction literally, have invoked the limitations of respondent superior to bar from relief claimants who, under the same circumstances, might have recovered from private parties under broadened state law ${ }^{14}$ or insurance provisions.

As a result of the respondeat superior restriction, a claimant injured by a negligent Government driver not on official business is for all practical purposes left without legal redress. Suit against the driver personally not only is often complicated by difficuties of serving process on transient Government employees, but is fruitless when the defendant is judgment-proof.15 Moreover, though the Tort Claims Act expressly authorizes the Attorney General to settle with a claimant, ${ }^{16}$ the Government is a hard bargainer. ${ }^{17}$ And resort

U.S. 957 (1949); United States v. Eleazer, 177 F. 2d 914 (4th Cir. 1949). But ef., Murphey v. United States, 179 F.2d 743 (9th Cir. 1950), 34 MIArg. L. REv. 225 (1950-51), where a divided court appears to have given the "line of duty" under the Tort Claims Act a broader meaning than the local concept of "scope of employment," although the cuurt purported to be applying local law.

14. See Long v. United States, 78 F. Supp. 35 (S.D. Cal. 1948) (Section 402 of CAL. VER. CODE, which imposes liability without regard to the dostrine of respindeat superior, held inapplicable to the United States since it would read out of the Tort Claims Act the qualifying phrase "while acting within the scope of his employment"); accord, Hubsch v. United States, 174 F. $2 d 7$ (5th Cir. 1949), cert. granted, 338 U.S. 814, rcmanded to district court for compromise settlemnt, $33 S$ U.S. 440 (1949), cerl. dismissed, 340 U.S. 804 (1950) ; Cropper v. United States, 81 F. Supp. 81 (N.D. Fla 1948). Bust see Clemens v. United States, SS F. Supp. 971 (D. Minn. 1950).

15. Six cases were explored where the courts found that the government employee involved was not acting within the scope of his employment at the time the plaintifi vas injured. In five cases there has been no compensation to date. In all five, hovever, no action was brought against the driver personally. Greenwood v. United States, 97 F. Sugp. 996 (D. Ky. 1951) ; Parrish v. United States, 95 F. Supp. 80 (1I.D. Ga. 1950); Clemens v. United States, \&8 F. Supp. 971 (D. Minn. 1950) ; Sanchez v. United States, 177 F. $2 d$ 452 (10th Cir. 1949) ; Cropper v. United States, S1 F. Supp. 81 (N.D. Fla 1948). Three drivers were judgment-proof (Sanchez, Greenwood, Clemens) ; a disputed complaint was served against another driver but was dropped when the court found that the driver's negligence was not the proximate cause of the accident (Parrish). No reason was given why there was no action against the driver in the remaining case.

Two cases reported difficulties of serving process on negligent servicemen. In one instance, the soldier resided in another jurisdiction; in the other, process vas served on a soldier in a disputed manner when he was in the state to testify, but was droppred on other grounds.

For full information, see communications to YALE LAW JouRNaL from parties' counsel, in Yale Law Library.

16. "The Attorney General, with the approval of the court, may arbitrate, compromise, or settle any claim cognizable under section $1346(\mathrm{~b})$ of this title, after the commencement of an action thereon." 28 U.S.C. $\$ 2677$ (Supp. 1951).

See Hubsch v. United States, 174 F. 2d 7 (5th Cir. 1949), ccrt. grasstrd, 338 U.S. $\$ 14$, remanded to district court for settlement, 338 U.S. 440 (1949), cort. dismissed, 340 U.S. 804 (1950) (allowing compromise settlement even where plaintiff lost on respondcat superior grounds in both the district court and the court of appeals).

17. In five cases explored, counsel replied on settlement. Only in one instance was such a settlement actually effected, and that was after the Sugreme Court had granted 
to a private relief bill also seems futile. ${ }^{18}$ In one instance, the Senate Judiciary Committee declared this road to recovery a circumvention of the Act's intent, although the respondeat superior restriction of the Act admittedly precluded compensation of a worthy claim. ${ }^{19}$

certiorari. Hubsch v. United States, 174 F. 2d 7 (5th Cir. 1949), cert. grantlcd, 338 U.S. 814, remanded to district court for settlement, 338 U.S. 440 (1949), ccrt. dismissed, 340 U.S. 804 (1950). Another reply indicated that a settlement had been agreed upon but was then repudiated by the Attorney General. In still another instance, the United States Attorney's office handling the case recommended a settlement, but the Attorney General's office refused to agree. See cases and communications note 15 supra.

This section was originally phrased so as to allow the Attorney General to scttle claims after their commencement "with a view to doing substantial justice." 60 STAT. 845 (1946). Although subsequent revisions have removed this terminology, its use in the original Act suggests an intention on the part of Congress to provide for cases where injustice or hardship would otherwise result. But apparently the provision has not been utilized for this purpose. In one case, for example, where the father of ten minor children was killed through the clear negligence of a soldier driving an Army truck, the Attorncy General's office refused to make even the $\$ 3,500$. settlement that the plaintiff was fintilly willing to accept despite the injustice involved and the clear moral obligation on the part of the Government to provide compensation. Communication from Pierce Wood. Attorney at Law, Dayton, Ohio, dated October 23, 1951, in Yale Law Library ; Bricf for plaintiffs, p. 13, Greenwood v. United States, 97 F. Supp. 996 (W.D. Ky. 1951).

18. To implement its basic policy of eliminating most private bills, Congress declared as part of the Legislative Reorganization Act that "[n]o private bill ... althorizing ... the payment of money ... for personal injuries or death for which suit may be instituted under the Federal Tort Claims Act... shall be received or considered in either the Senate or the House of Representatives." 60 STAт. 831 (1946). Under a ruling of the Claims Subcommittee of the House Judiciary Committee, a statement must be made in the bill that the accident occurred while the federal employee was not acting within the scope of his employment, before the bill can even be introduced. Furthermore, the committee feels that a stronger case is presented when legal remedies have been cxhausted. Communication to the Honorable John J. Dempsey, United States Representative, from Harry L. Bigbee, Attorney at Law, Santa Fe, N.M., dated January 31, 1951, duplicate excerpt in Yale Law Library. Thus in cases where the question of scope of cmployment is in doubt, claimants may be forced to go through the expensive process of prosecuting an unsuccessful suit before they can have a private bill introduced in their interest.

Even where a claimant has sued the United States and been defeated on "scope of employment" grounds, he has little prospect of compensation. Of five such cases studied, two reported that private legislation had not been attempted. One reported that a private bill is planned; one reported that such a bill had been introduced but had died in committee; and one reported that a private bill had been introduced but had been specifi. cally rejected. See cases and communications note 15 supra. See also note 19 infra.

For other cases involving Government vehicles in which the issue of scope of employment was involved, see Murphey v. United States, 179 F. 2d 743 (9th Cir. 1950) (within scope); Christian v. United States, 184 F. 2d 523 (6th Cir. 1950) (outside scope); Alexander v. United States, 98 F. Supp. 453 (E.D. S.C. 1951) (outside scope); Mackay v. United States, 88 F. Supp. 696 (D. Conn. 1949) (outside scope); Lowe v. United States, 83 F. Supp. 128 (W.D. Mo. 1949) (within scope).

19. "The question here is whether a claimant who may purste a remedy under" general legislation, but who fails to recover because of the provisions of the general legis- 
While legislative history is inconclusive, Congressional failure to harmonize compensation under the Act with the effective recovery achieved in most states through statutes and insurance provisions may well have been inadvertent. The Tort Claims Act, passed as part of the Legislative Reorganization Act of 1946, received but minor consideration by Congress at the time of its enactment. ${ }^{20}$ Moreover, since respondeat superior has retained its vitality in state law as to non-vehicular negligence, ${ }^{21}$ essentially identical criteria determine recovery from the Government and private employers in such cases covered by the Act. Only as to automobile accident compensation have state statutes and insurance practice undermined "scope of employment" as a basis of recovery for negligent injury. ${ }^{22}$ Thus, only in motor vehicle negligence cases has the Act failed to realize the Congressional purpose of placing the United States in the same position as a private employer. ${ }^{23}$ In fact, a

lation, may then successfully look to the Congress for relief. In brief the question is whether the Congress shall pay claims for injuries caused by the wrongiul act or cmission of the United States in a case when the employee is not acting within the scope of his office or employment.

"It is the belief of your committee that Congress expressed its intent in the general legislation and that this claimant should not be permitted to circumvent such intent by private legislation, but rather the remedy is in the proper amending of the over-all general law. In addition, it appears the claimant has had his day in court."

Report to accompany S. 483, from the Committee on the Judiciary, 81st Cong., 1st Sess. (1949). Confidential Committee Print, p. 3. The bill was introduced on behalf of a claimant in a case where the court said a private employer under the same circumstances would have been liable. Cropper v. United States, S1 F. Supp. 81, \&2 (N.D. Fla. 1948).

20. The basic purpose of the Legislative Reorganization Act of 1946 was to provide for increased efficiency in the legislative branch of the Government. Since a major portion of the Act was devoted to organizational changes in Congress, most of the legislaturs" attention was focused upon that problem. See, e.g., SEN. REP. No. 1400, 79th Cong., 2d Sess. (1946) (only four pages of 40-page report devoted to Tort Claims Act); 92 Co:sc. REC 10092 (1946) (practically no debate on Tort Claims Act in House of Represent3tives at time of passage). There were no hearings in 1946 on the tort claims provisions. But similar bills had been considered at earlier times by committees in buth houses. See, e.g., Hearings before the Committee on the Jidiciary on H.R. 5373 and H.R. 6173, 77th Cong., 2d Sess. (1942) ; SEN. Rep. No. 1196, 77th Cong., 2d Sess. (1942). Even in such earlier considerations, however, the issue of broadened recovery in private automobile cases does not appear to have been brought to the attention of Congress.

21. See Note, 2 A.I.R. $2 d 413$ (1948); 35 Aar. Jur. 985.

22. See p. $2 x x$ supra.

23. "The United States shall be liable, respecting the provisions of this title relating to tort claims, in the same manner and to the same extent as a private individual under like circumstances, but shall not be liable for interest prior to judgment or for punitive damages." 28 U.S.C. $\$ 2674$ (Supp. 1951).

See the remark of Mr. Scrivner in the House of Representatives at the time of passage of the Act that "[i]f I read this language correctly, the recovery will be against the Government just exactly as against the private individual." 92 Conc. REC $1(6, y 2$ (1946). Sce also Young v. Crited States, 184 F. 2d 587, 590 (D.C. Cir. 1950); Rushford v. United States, 92 F. Supp. 874,876 (N.D. N.Y. 1950). 
somewhat similar statutory flaw was remedied in 1947 to permit recovery against the Government where, because of peculiar state law, literal reading of the Act had precluded it. ${ }^{24}$

To ensure victims of negligent Government drivers a chance of recovery at least equal to suit against private parties, Congress should further amend the Tort Claims Act. ${ }^{25}$ Elimination of the scope of employment restriction would make Governmental and private legal liability coextensive under state law. But such a change would not be enough to make recovery opportunity commensurate with that in cases involving private employers; claimants would still be deprived of the recovery benefits of "omnibus clauses" in automobile accident insurance policies. Short of accepting absolute liability, Congress by incorporating into the Act doctrines common in local practice could assure recovery in most vehicular negligence cases. Congress, for example, could apply to the Government the agency provisions of the District of Columbia Financial Responsibility Law ${ }^{20}$ it once enacted to broaden the basis of private liability. Under that statute, express or implied consent by the owner to another's use of a vehicle is the basis of vicarious liability, and ownership is prima facie evidence of consent. ${ }^{27}$ But since by law Government vehicles may be driven only on official business, ${ }^{28}$ this technicality might be held to rebut consent narrowly interpreted. Hence, Congress should also enact a broad definition of consent. Under a frequent state interpretation, the

24. The original Act declared that the United States should not be liable for punitive damages. But Alabama and Massachusetts allowed exclusively punitive damages for wrongful homicide. In recommending passage of an amendment that would allow the Government to be sued for compensatory damages in such states, the House Judiciary Committee reported that "[i]ts passage will remove an unjtst discrimination $n c v c r$ intended, but which works a complete denial of remedy for wrongful homicide." (Emphasis added.) H.R. Rev. No. 748, 80th Cong., 1st Sess. 2 (1947).

25. Prompt action is desirable because of the great number of government vehicles now in operation. In 1950, there were 81,666 vehicles operated in the United States by civilian federal agencies. Department of Commerce, Bureau of Public Roads, Table MV-7, 1950 (April, 1951). As of June 30,1949, there were 102,205 military vehicles operating on United States highways. Although the number of such military vehicles fell to 79,665 by January, 1950, presumably it will again grow as the armed forces expand. Communication to the Yale Law Journal from Philip F. Hines, Assistant to the Deputy Director, Office of Public Information, Department of Defense, dated November 19, 1951, in Yale Law Library.

26. D.C. CODE $\$ 40-403$ (1940).

27. Ibid. See Forrester v. Jerman, 90 F. 2d 412 (D.C. Cir. 1937) (statute substituted consent for respondeat superior as basis of liability); Rosenberg v. Murray, 116 F. $2 d 552$ (D.C. Cir. 1940) (proof of ownership shifts to defendant the burden of proving a lack of consent).

28. 59 Stat. 132 (1945), 5 U.S.C. $\$ 78$ (c) (2) (1946); see also 32 C.F.R. $\$ 634.1$ (Supp. 1950) (comparable Army regulation). But the law is not always observed. See, e.g., remarks by Senator Bridges, 92 Conc. Rec. 6559 (1946) ("... Congress should talic steps to find out why the law is not being lived up to..."). 
owner's mere initial permission ${ }^{29}$ to use a vehicle is held sufficient consent to impose liability upon him even for the driver's subsequent unauthorized actions. ${ }^{30}$ Under this "initial permission" test, once the Government checlied out a vehicle to a driver, liability for his negligence on unauthorized departures from official business would automatically follow. In effect, the Government would assume accident responsibility for the negligent use of its vehicles in virtually any case short of conversion. ${ }^{31}$ This test not only best protects the public by a broad rule of liability but furnishes the most objective standard for a determination of consent. 32 Under such statutory provisions basing lizbility on consent broadly defined, Government vehicular responsibility, although not strictly following each individual state practice, ${ }^{33}$ would assure tort claimants recovery results approximating those realized against private parties under advanced state law and insurance practice.

Liability for vehicular negligence is a recognized expense in any large enterprise. By accepting a realistic degree of responsibility for the consequences of negligent use of its vehicles, the Government would merely be serving in

29. "Initial" permission refers to that permission given to a driver in the first instance to use the vehicle, as distinguished from the further problem of whether he has permission for the actual use he may subsequently malse of the vehicle. Sce Hodges v. Ocean Accident \& Guarantee Corp., $66 \mathrm{Ga}$. App. 431, 435, 18 S.E. 2d 28, 31 (1941), ccrt. denied, 316 U.S. 693 (1942). Such initial permission may be either given by express grant or may be implied from usage and practice of the parties prior to the aceident. See, e.g., Farmer v. United States Fidelity \& Guarantee Company, 11 F. Supp. 542, 543 (IS.D. Ala. 1935) (express permission); Maryland Casualty Company v. Konan, 37 F. 2d 449, 450 (2nd Cir. 1930) (implied permission). See Hinton v. Indemnity Ins. Co., $175 \mathrm{Vs}$. 205, 214, \& S.E. 2d 279, 281 (1940).

30. See, e.g., Jefson v. London Guarantee \& Accident Co., 293 I1l. App. 97, 11 N.E. $2 d 993$ (1937) ; Parks v. Hall, 189 La. 849, 181 So. 191 (1938); Stovall v. New York Indemnity Co., 157 Tenn. 301, S S.W. 2d 473 (1928). Cf. Beggs v. Butler, $129 \mathrm{Fla}$. 324, 327, 176 So. 174, 176 (1937).

31. See Wilson v. Farnsworth, (La. App.) + So. 2d 247, 250 (1941).

32. See Stovall v. New York Indemnity Co., 157 Tenn. 301, 314, 8 S.W. 2d 473, 477 (1928) ; Parks v. Hall, 189 La. S49, 858, 181 So. 191, 194 (1938).

33. In addition to the most advanced "initial permission" test deseribed above, which is utilized in quite a number of jurisdictions, there are two other tests used in state practice. Some states hold that such initial permission is sufficient to constitute consent so long as the employee's conduct involves no more than a "slight deviation" from such permission. See, e.g., Hodges v. Ocean Accident \& Guarantee Corp., 66 Gz. App. 431, 436, 18 S.E. 2d 28, 32 (1941), cort. denicd, 316 U.S. 693 (1942); Fritz Anderson v. Standard Oil Co., and Another, 204 Minn. 337, 283 N.W. 571 (1939); State Farm Mlut. Auto. Ins. Co. v. Cook, 186 Va. 65S, 43 S.E. 2d 863 (1947). A few cüurts, however, hold that the actual use of the vehicle at the time of the accident must be the one for which initial permission was given before they will find consent. See, c.g., Johnson v. American Auto. Ins. Company, 131 Me. 28s, 161 Atl. 496 (1932); Sauriolle v. O'Gorman, 86 N.H. 39, 163 Atl. 717 (1932). For discussion of these three tests and extensive case citation, see Notes 5 A.L.K. 2d 600 (1949) ; 159 A.L.K. 1369 (1945); see alsu Miller, The Omtiluis Clause, 15 Tulane L. Rev. 422,424 (1941). 
the capacity of its own insurer. ${ }^{34}$ The cost of Governmental vehicular negligence would be distributed to all the nation's taxpayers rather than thrust upon the individual accident victim.

34. By thus serving as its own insurer, the Government would also provide greater protection for its employees. The increased liability of the United States would reduce any incentive to sue the negligent employee personally. Furthermore, under the Act, recovery from the Government bars any additional claim against the employee. 28 U.S.C. $\S 2627$ (Supp. 1951). Like other employers, the Government would still have a right of action against the employee involved. See Washington Gas Light Co. v. District of Col, 161 U.S. 316, 327 (1896). As in the case of railroads and other large enterprises, however, it is improbable that this right would ever be exercised. 